\title{
論評に対する原著者の回答
}

\section{Author's Replies to the Comments}

\section{阿久津氏の論評について}

阿久津氏の論評性, 縄文前期末層に関する珪藻組成打 よびそれの埋積する谷状部の形成営力と海退との関係で ある。

縄文前期末層の珪藻組成について, 詳細は「寿能泥炭 層遺跡発掘調查報告書一自然遺物編一」を参照していた だくとして，第 1 地点（no. 16〜20）に抢ける優占種の 出現頻度をあげると表 1 のごとくである. 汽水産広塩性 の Coscinodiscus lacustris を主とし, Coscinodiscus margniatus, Melosira granulata, Melosira italica など海産や淡 水産浮遊種も比較的多く産している. この珪藻組成から 縄文前期末層を汽水成堆積物としたが，海進時の汽水成 堆積物とした縄文前期 $\mathrm{A}$ 層とは, Nitzschia cocconeiforism の量など組成の上で差異が認められる.

縄文前期末層の埋積する谷状形の様子をみると, 調查 地域南西部では谷も深く明膫で基底に粘土の角磁片など 粗粒堆積物が認められるが，北部では谷も浅くなり粗粒 堆積物が目立つことなく, 全体的に不明瞭となってい る.このことは海退にともなら河川の延長部として, 河 川の侵食により形成された谷地形ではなく, 海岸にでき ていた「謴一及怙一」の上うな凹地が，海退時の波食作 用によって若干の削剝と粘土破片の埋積をうケたるのと 推定している. また, 海退の進行も阿久津氏の指摘のよ らに, 単純に推移していったとは考兄ていないが, 縄文 前期末のころに若干の海面停滞はあったとしても, 谷地 形の中に波食台を認定することができなかったので，長 期間の海水面の停滞あるいは海進のような海面上昇など

表 1 寿能泥炭層遺跡における繩文前期末層（第 1 地点) の主要珪藻の出現頻度

\begin{tabular}{lcrrr} 
& 16 & 18 & \multicolumn{1}{c}{19} & \multicolumn{1}{c}{20} \\
\hline Cosoinodiscus zacustris & 26.4 & 23.2 & 21.5 & 26.9 \\
C. marginatus & 15.5 & 6.2 & 9.5 & 9.1 \\
Cyolotelia striata & -- & 4.3 & 4.4 & 9.1 \\
Diploneis smithii v.pumiza & 3.0 & 3.4 & 1.1 & 2.3 \\
Melosira granulata & 4.0 & 18.0 & 15.0 & 8.2 \\
M. italica & 7.1 & 10.2 & 5.8 & 2.6 \\
M. sulcata & 0.7 & 0.9 & 4.0 & 4.7 \\
Nitzschia coconeiformis & 1.7 & -- & -- & 0.3 \\
N. granulata & 1.4 & 0.9 & 0.7 & 1.8 \\
Fhopalodia gibberula & 3.0 & -- & 0.4 & 3.5 \\
R. musculus & 1.7 & 0.6 & 1.5 & 0.3
\end{tabular}

堀口万吉

Mankichi HoriguahI

はなかったものと考光る. 海水面の高さや海水面の変動 についての根拠となりらる現象をとらえて, さらに細か く検討することを望んでいる.

\section{藤氏の論評について}

\section{1. 層序区分と考古編年の対応}

藤氏も論及しているよらに考古遺跡の発掘調查中に併 行して自然科学的調查を行い, 考古編年と自然堆積物の 皤序区分を正しく対比することは困難なことが多い。こ のことは寿能遺跡の調査を進めるにあたり，とくに留意 したことである.遺跡の発掘は通常平面的に削剝してい くことが多く, 問題の生じたときにはすでにその地層の 上部は削剝されていると云らことが多々ある.そのため 試料の採取層準や位置の確認についての精度が悪くなる ことがある.この対策としては, 考古研究者と一緒に每 日の発掘に参加して層序編年のための試料を細かく採取 することであり，また，トレンチによる地層断面の調査 を多用して, 地層の累重関係を確認しながら, 地層の層 序区分を行うことである・いったん取り上げられてしま った試料（材なども）は, その包含状態や産山層準を正 しく決定することが，むずかしいことを考光てみる必要 がある・

また, 考古学研究者の中には ${ }^{14} \mathrm{C}$ 年代を軽視与る人 もいるが, 遺跡の調查地点が自然環境の研究地点として 最適の場でないことが多く，とくに台地上では自然環境 解析のための試料包含層がうすく, 周辺低地の厚い地層 の方が有効な資料を提供することが多いことを考える と, 考古編年と ${ }^{14} \mathrm{C}$ 年代を対応させた層序編年表の作 成が要求される.すなわらこの編年表によって, 自然科 学的各種の研究・分析の結果を, 当時の人類活動の場の 条件 (自然環境) の復元資料として，大きく役立たせる ことができる．藤氏の期待と同様に筆者もとの完成に努 力と期待をかけている.

\section{2. 縄文海進の最高頂期}

藤氏の指摘のように縄文海進に関する研究は漠然と海 進の時期や高度を決めるのではなく, さらにきめ細い研 究をすべきである。

寿能遺跡では, 縄文海進の最高頂期を諸磯 a 期とした 
が，本論でも記しているように，この年代を示す直接の 資料は得られていない，この点では藤氏の指摘するよう にこの值は推定の域を出ていない，しかし，寿能遺跡で 最高頂期の年代を考光るとき，珪藻化石よりみて縄文前 期 $\mathrm{B}$ 層の上部が水樑の大きかった時期の堆積物と考兄ら れる.しかし，この部分からの土器の産出がなく，時代 の判定は下部の粘土層からの黒浜式土器の産出々, 縄文 前期 $\mathrm{B}$ 層を切る谷状部の汽水成の堆積物 (縄文前期末層) に入っている諸磯 $\mathrm{b}$ 式と十三菩提式土器の産出の二つの 資料より考えざるを得ない，そこで本論でふれているよ うに中間の時期とした。 また, 最高頂期の海域が最も拡 大したと考えると, 土器の混入之土器産出の可能性も考 慮する必要がある。これらのことから寿能遺跡に特汁る 最高頂期は諸磯 $\mathrm{a}$ 期と推定した。

藤氏の云らように, 縄文海進最高頂期の海水面の高度 や時期の決定には, 直接の証拠が必要である.海水準の 高さについては，海成層の上面が必ずしも最高海水準を 示しているとは考兄られない, 当時の汀線の確認が必要 で㟧，その時期（年代）についても, 汀線での年代決 定が最良の方法とい方よう. しかし，ここから得られた 数值にしても, あくまでその地点でのものであり, 地殻 変動やその立地の地域的, 広域的な検討の上で, 最高海 水準にかかわるるのとして確認がなされなければならな W.

寿能遺跡での最高頂期の高さと時代については, さら に大宮台地や奥東京海地域の中での検討を修正を行いた いと考光ている.

\section{3. 縄交前期の古植生}

寿能遺跡に括ける花粉分析結果を総合してみると，本 遺跡では沖積世を通じて照葉樹（アカガシ亜属）が落葉 広葉樹 (コナラ亜属)を上まわることなく，現在にいた っている.このことは本地域の極相林として照葉樹林が 想定されていることと相違した結果となっている.さら にこれと同様な結果は，大宮台地北方の加須低地に打许 る花粉分析結果からす出されて抒り, 落葉広葉樹林の卓 越は，関東平野中央部（大宮台地や加須低地）の大きな 特徽と考学られる。

藤氏は照葉樹林帯の境界が年平均気温 $14^{\circ} \mathrm{C}$ 等温線 一致し，縄文時代の温暖気候を考劣ると，関東平野の大 部分は照葉樹林带にあったことが，理論的に考觉られる と述べている.そして本論で述べたような落葉広葉樹林 の卓越は, 照葉樹林帯の境界の訂正でなく, 降水量や土 地的条件によるか，植生の遷移の途中で止ったのか，縄 文人の伐採による二次林の形成など，いくつかの観点の 上からの地域的な検討が必要であることを指 摘してい る.

筆者は関東平野中央部は太平洋から遠くはなれ，「空 っ風」で知られるような北西季節風の強い地域であり, 委た，降水量が少ないなど気候的条件が関与しているこ と.さらに，この地域の縄文時代の古地理を考光ると， 東と西を中川や荒川の低地（海）飞限られている弧立し た台地であることなど，土地的条件が大きくかかわって いると考光ている. 今後, さらに植生研究者の意見を参 考にして検討をすすめていきたいと考劣ている. 